\title{
Biochar: Agronomic and environmental potential in Brazilian savannah soils
}

\author{
Fabiano A. Petter ${ }^{1}$ \& Beata E. Madari ${ }^{2}$
}

\begin{abstract}
Due to the high activity of microorganisms, the loss of soil organic matter is high in tropical regions. This loss becomes even greater if the soil is managed improperly or when there is no technology that leverages the permanence of the soil carbon by maintaining appropriate levels of organic matter, providing chemical, physical and biological soil improvements and contributing to reduce $\mathrm{CO}_{2}$ emissions to the atmosphere. Due to its aromatic structure, biochar is a highly stable form of carbon in the soil that may contribute to the reduction of greenhouse gas emissions, such as $\mathrm{CO}_{2}, \mathrm{~N}_{2} \mathrm{O}$ and $\mathrm{CH}_{4}$, and act as a soil conditioner, improving the physical and chemical properties of the soil. Biochar may also result in increased productivity due to the improvement of soil attributes or a possible electrophysiological effect. Research over the past decades has demonstrated the potential of biochar as a soil conditioner, improving fertility and nutrient-use efficiency, in addition to maximising the productivity of crops, such as soybean and rice.
\end{abstract}

Key words: pyrogenic carbon, fertility, yield, greenhouse gas emission

\section{Biochar: Potencial ambiental e agronômico em solos de cerrado}

\begin{abstract}
RESUMO
Em solos de regiões tropicais a perda de matéria orgânica já é grande em função da alta atividade dos micro-organismos, tornando-se ainda maior com o manejo inadequado ou em razão da falta de uma tecnologia que potencialize a permanência do carbono no solo mantendo os teores de matéria orgânica em níveis adequados, proporcionando melhorias sobre os atributos químicos, físicos e biológicos do solo e contribuindo para a redução da emissão de $\mathrm{CO}_{2}$ para a atmosfera. O biochar, dado à sua estrutura aromática, é uma forma de carbono relativamente estável no solo, que pode contribuir para a redução da emissão de gases de efeito estufa, tais como $\mathrm{CO}_{2}$ e $\mathrm{N}_{2} \mathrm{O}$, e atuar como condicionador de solo, contribuindo com a melhoria dos atributos do solo em função de suas características físico-químicas, proporcionando, assim, o aumento da produtividade, seja em função da melhoria dos atributos do solo ou através de um possível efeito eletrofisiológico. Trabalhos ao longo de décadas demonstram o potencial do biochar como condicionador de solo, aumentando a fertilidade e a eficiência no uso dos nutrientes e, em conseqüência, maximizando a produtividade de culturas, como soja e arroz.
\end{abstract}

Palavras-chave: carbono pirogênico, fertilidade, produtividade, emissão de gases de efeito estufa 


\section{INTRODUCTION}

Anthropogenic activities to produce food have led to environmental degradation, especially when they occur in areas that should be preserved. The cutting and burning of forests cause a natural loss in soil fertility, decrease the soil organic matter and release carbon dioxide $\left(\mathrm{CO}_{2}\right)$ and other greenhouse gases (GHG) to the atmosphere, thus contributing to global warming (Machado, 2005).

The $\mathrm{CO}_{2}$ emissions from the soil caused by human action account for approximately $25 \%$ of the total $\mathrm{CO}_{2}$ emissions on Earth (Bouwmann \& Germon, 1998). The soil organic matter (SOM) is of great importance in the formation and maintenance of the chemical, physical and biological properties of savannah soils, contributing up to $80 \%$ of their cation exchange capacity (CEC) (Pacheco \& Petter, 2011). However, in this biome, the mineralisation rate of the SOM reaches high levels in the decomposition of waste due to high temperatures and microbial activity, both of which reduce the amount of these compounds in the soil (Torres et al., 2005).

New systems and production technologies that are appropriate for different environmental conditions and reconcile food production with biodiversity preservation, soil and water conservation and contribute to the sequestration of excess carbon in the atmosphere can reduce the environmental impact of anthropogenic activities. An alternative for carbon fixation in the soil is the application of biochar. Biochar (carbonised biomass) can be obtained through pyrolysis processes (Novotny et al., 2009) and is a byproduct of thermal or electrical energy generation and bio-diesel or bio-oil production from biomass, all of which are renewable energy sources. Examples of pyrolysable biomass include rice husk, a byproduct obtained after the processing of rice (Araújo Neto et al., 2009), or sugarcane bagasse from sugar and ethanol production. These byproducts are currently being used for electrical or thermal energy generation by simple burning for grain drying or the proper functioning of industrial plants (Souza \& Azevedo, 2006) and are eligible to obtain carbon credits within the standards of the Kyoto Protocol. In the future, energy may be produced by utilising these byproducts with adequate pyrolysis technology, enabling the fixation of carbon in the pyrolysis residue (biochar) in addition to generating energy. Another source of biochar is the charcoal used by metallurgical industries to replace coal during the production of pig iron that is obtained from planted forests and is recognised as a clean development mechanism (CDM) (Machado, 2003).

Charcoal, derived from the carbonisation of lignocellulosic materials, e.g. wood, is an option for the production of pyrogenic carbon in industries using furnaces suitable for this purpose, without the release of $\mathrm{CO}_{2}$ and other non-condensable and condensable gases into the atmosphere (Yang et al., 2007).

The use of pyrogenic carbon or charcoal is an alternative for increasing biomass and grain production in areas of degraded pastures, thus favouring the preservation of virgin lands rather than increasing planted areas. Due to such characteristics as its stability, reactivity, degradation time, molecular structure, specific surface area and hydrophobicity, charcoal is considered relatively inert and highly stable in the soil and may contribute to the improvement of the chemical, physical, hydraulic and biological properties of the soil.

\section{CharcoAl IN THE SOIL}

Small fragments of charcoal are found in most soils, especially in the form of pyrogenic carbon or black carbon, resulting from natural or human induced burning (Jantalia, 2007).

Charcoal is generally reported to be highly aromatic and hydrogen-deficient in its structures that are consequently relatively inert in the soil environment (Hammes et al., 2006; Novotny et al., 2009). Charcoal is also mostly hydrophobic and usually has a high surface area of 200 and $400 \mathrm{~m}^{2} \mathrm{~g}^{-1}$ due to its high porosity (Kishimoto \& Sugira, 1985). However, the structure and, therefore, the reactivity and hydrophobic properties of chars depend, at least partially, on the material source, the conditions of their formation, such as temperature and heating time (Elizalde-Gonzales et al., 2007), the moisture from the plant material and oxygen availability (Tsai et al., 2007). Nevertheless, chars, which are considered stable in the soil compared to other forms of organic matter, also undergo biodegradation and transformation.

Pyrogenic carbon is the fraction of SOM with the highest half-life on Earth (Pessenda et al., 2004): fractions containing pyrogenic carbon are found in large quantities in "Terra Preta de Índio", also called anthropogenic or Indian dark earth, in the Amazon Basin and has been radiocarbon-dated at over 1000 years old (Kämpf \& Kern, 2005). Although the longevity of this material in the soil is evident, the quantitative rate of decomposition still requires evaluation using methodologies that could provide more accurate data.

The understanding of the reactivity of pyrogenic carbon in the soil is of fundamental importance for its use as a soil conditioner to sequester carbon from the atmosphere and improve soil characteristics. In the short term, the persistence of chars in the soil without undergoing major structural changes can help reduce $\mathrm{CO}_{2}$ emissions. However, charred biomass also undergoes decomposition processes in the soil, albeit at a much lower rate. This property of slow degradation make chars part of the global carbon cycle.

\section{PRODUCTION OF CHARRED BIOMASS}

Brazil is the largest producer of charcoal (Santiago \& Andrade, 2005), accounting for over $35 \%$ of the world's production. In Brazil, the production of charcoal from eucalyptus (Eucalyptus sp.) plantations is important for the metallurgical industry, and this process is categorised as a Clean Development Mechanism (CDM) under the Kyoto Protocol (Sato \& Azevedo, 2008). In the traditional process of charring, approximately $35 \%$ of the carbon is fixed in the charcoal, and the remainder is emitted into the environment as smoke and non-condensable gases, such as $\mathrm{CO}_{2}$, carbon monoxide $(\mathrm{CO})$ and methane $\left(\mathrm{CH}_{4}\right)$ (Moura et al., 2010). 
However, there are technologies that are able to recover up to $50 \%$ of these byproducts of carbonisation in the form of condensable gases, minimising the environmental pollution.

The product of the carbonisation of lingo-cellulosic biomass in a controlled, oxygen $\left(\mathrm{O}_{2}\right)$ deficient and relatively low $(<700$ ${ }^{\circ} \mathrm{C}$ ) environment temperature (Lehman \& Joseph, 2009) will hereafter be referred to as "biochar", as the interest is related to its capacity of altering the chemical, physical and biological characteristics of the soil to achieve an environment that is conducive to good plant growth, while reducing greenhouse gas (GHG) emissions and increasing carbon sequestration in the soil.

The amount of carbon produced by burning depends on the material source, temperature and time of exposition (Trompowsky et al., 2005). During the pyrolysis of plant materials, a large amount of mass is lost, mainly in the form of volatile organic compounds $\left(\mathrm{CO}, \mathrm{CO}_{2}\right.$ and $\left.\mathrm{CH}_{4}\right)$ and water $\left(\mathrm{H}_{2} \mathrm{O}\right)$, resulting in a considerable reduction in the initial volume (Downie et al., 2009) as well. However, during thermal conversion, minerals and carbon skeletons help maintain the rudimentary structure and porosity of the original material (Wildman \& Derbyshire, 1991).

The carbon contained in biochar is composed mostly of aromatic structures, which are characterised by linkages in the form of benzene rings of $\mathrm{C}$ atoms with oxygen $(\mathrm{O})$ or hydrogen (H) (Lehman \& Joseph, 2009). These links between CO and CH aromatic structures govern the stability of biochar and are used to measure the degree of aromaticity of the compounds (Hammes et al., 2006). An O:C ratio below 0.3 indicates a high degree of aromaticity (Baldock \& Smernick, 2002), as it agrees with the premise that the raw material should be carbonised in an oxygen deficient environment to obtain a high concentration of biochar $\mathrm{C}$.

\section{PhysicAl AND ORGANO-CHEMICAL PROPERTIES OF} BIOCHAR

Most studies related to the pyrolysis of plant materials are aimed at their use as adsorbents in the separation and purification of gases, liquids and solid compounds and thus refer to the production of activated carbon (Lima et al., 2006; Pereira et al., 2008). However, the cost of producing activated carbon is relatively high, making its use impracticable as a soil conditioner in agricultural systems. Yet, much of the information on the production and behaviour of activated carbon serves as the basis for the use of biochar, as the physical characteristics are similar, especially with regard to its main function of adsorbing compounds, regardless of whether they are in a liquid, solid or gaseous state.

The carbonisation temperature is a major factor that influences the physical properties of biochar (Trompowsky et al., 2005). The combustion of wood leads to a mass loss in the form of volatile compounds, which include the loss of "cell juice", hemicellulose, cellulose and lignin, forming compounds with high carbon content (Downie et al., 2009).

Through the use of nuclear magnetic resonance (NMR) spectroscopy, it is possible to identify the range of compounds at different carbonisation temperatures by means of the spectral signals emitted by their structures (Novotny et al., 2007). Krull et al. (2003) found that, at $200{ }^{\circ} \mathrm{C}$, the signal intensity associated with the structures of cellulose and hemicellulose (carbohydrates) decreased, whereas the signal strength of lignin increased. This was attributed to the fact that the temperature of lignin degradation is larger than that for hemicellulose. These changes reflect the conversion of the structures, while considering the chemical characteristics of the material. Such changes in the structure lead to a mass loss during transformations. With the loss of these compounds, pores are formed, contributing to the increased surface area the biochar (Krull et al., 2003).

The porosity of biochar may be divided into micro-, mesoand macropores (Figures 1 and 2) with a diameter < $2 \mathrm{~nm}, 20-50$ $\mathrm{nm}$ and $>50 \mathrm{~nm}$, respectively (Rouquerol et al., 1999). The micropores present function in the adsorption of gases, whereas the mesopores are associated with the adsorption of liquid and solid compounds. The macropores are important feeders of smaller-diameter pores, aiding in the transport of molecules concentrated by the meso- and micropores (Wildman \& Derbyshire, 1991), and are also relevant to the movement of roots through the soil and habitat for a variety of soil microorganisms (Kolb et al., 2009).

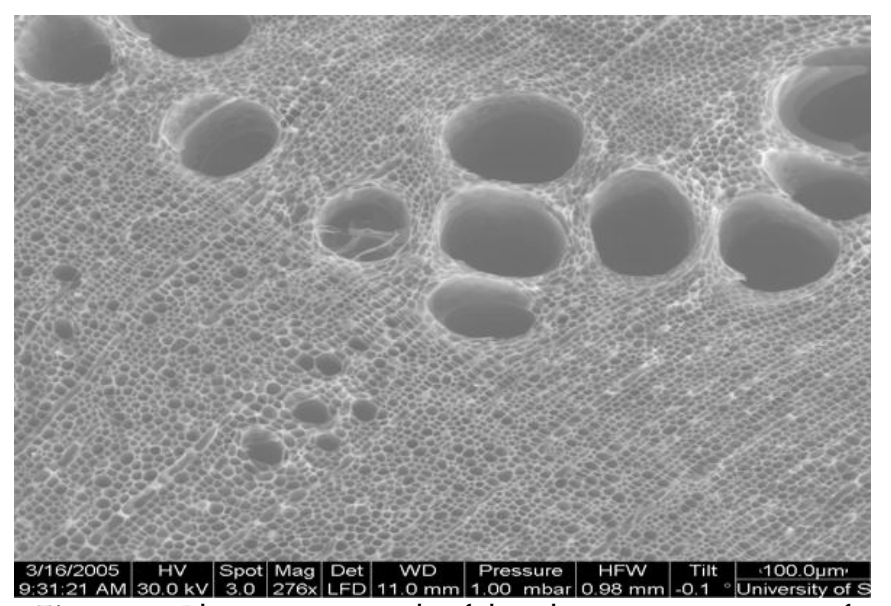

Figure 1. Photomicrograph of the electronic structure of a charcoal (Leij et al., 2006)

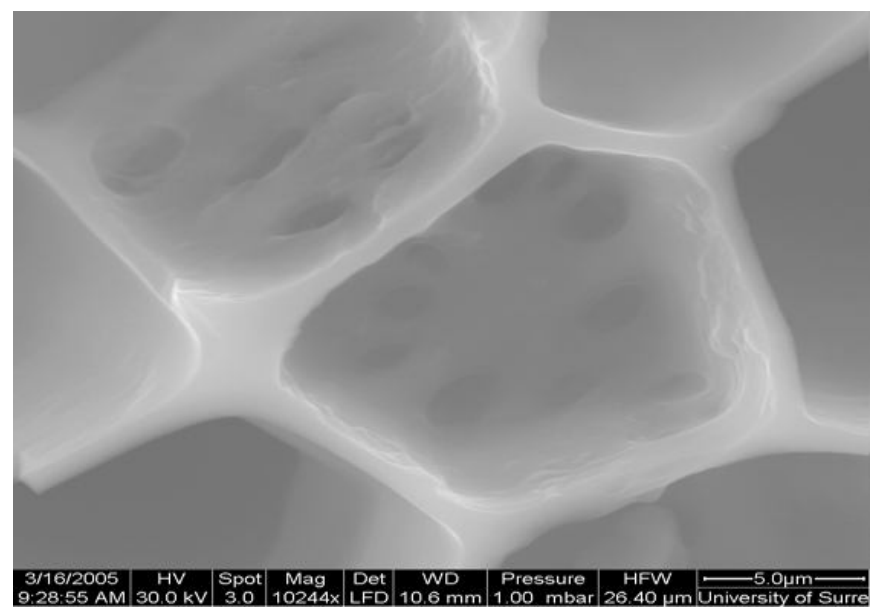

Figure 2. Electron photomicrograph of a charcoal pore (Leij et al., 2006) 
The porosity of biochar is responsible for most of the reactive load areas. These peripheral structures may be hydrophilically or hydrophobically reactive, and this variation is due to the electro-negativity of the functional groups, such as $\mathrm{OH}, \mathrm{NH}_{2}, \mathrm{OR}$, or $\mathrm{O}(\mathrm{C}=\mathrm{O}) \mathrm{R}$, that are attached to the carbons of the aromatic structures, generating a heterogeneous chemical surface (Brennan et al., 2001).

Given this, it is clear that the physical and chemical characteristics of biochar, such as its porosity, specific surface area and electrochemical charges, are closely related to the carbonisation temperature and concentrations of $\mathrm{O}_{2}$ used during production.

\section{BIOCHAR AND CHEMICAL, PHYSICAL AND BIOLOGICAL SOIL CHARACTERISTICS}

Soils have different chemical, physical and biological characteristics, depending on the nature of the mineral matrix and the organic matter and the way they are associated (Brady $\&$ Weil, 2008). However, when materials with different characteristics are present, there may be changes in the behaviour of the soil, changing the characteristics. Due to its higher specific surface area, the presence of biochar may contribute to significant changes in the soil physical properties by changing its texture, structure, consistency and porosity, pore size, size distribution and density (Downie et al., 2009). According to Downie et al. (2009), the change in the soil physical properties due to the presence of biochar may result in increased plant growth because there is an increase in water availability in the area close to the root system that is mainly determined by the physical composition of soil horizons.

Because of its porosity and, consequently, its high specific surface area, charcoal can significantly increase the capacity of water retention, especially in sandy soils (Cohen-Ofri et al., 2006). However, the aromatic structure, which has hydrophobic characteristics, can reduce the penetration of water in the pore spaces of soil aggregates, thus increasing the aggregate stability (Glaser et al., 2002).

All of these changes in the physical soil properties can lead to changes in the chemical and biological properties of the soil due to the availability of chemically reactive groups and habitats for soil microorganisms (Brady \& Weil, 2008).

The specific surface area of soil is an extremely important feature that influences fertility, water and air availability, nutrient cycling and microbial activity (Kolb et al., 2009). As reported previously, the specific surface area of biochar, approximately 200 to $400 \mathrm{~m}^{2} \mathrm{~g}^{-1}$, is comparable to that of the clay fraction. The cation exchange capacity (CEC) is associated with the specific surface area, but it is highly dependent on chemically reactive sites, which are formed over years during microbial degradation, altering the chemical and physical characteristics of biochar (Cohen-Ofri et al., 2006). According to Cohen-Ofri et al. (2006), these changes result from the increase of electric charges arising from the oxidation of biochemical compounds, leading to an increase in phenolic, hydroxyl, carbonyl and quinone compounds and, consequently, an increase in the overall negative surface charge that results from the replacement of positive charges in the oxidation process. This can explain the increase in the CEC of biochar, over time, in soils.

In Brazil, an example of the beneficial effect of charcoal, or pyrogenic carbon, for the fertility of soils are the anthropogenic dark earths that were made by the pre-Columbian peoples of the Amazon Basin (Kämpf \& Kern, 2005). According to Kämpf $\&$ Kern (2005), these soils contain large amounts of pyrogenic carbon that are up to 2.5 times the content in the soils that are adjacent and non-anthropogenic. This carbon, which probably originated from the periodic burning and carbonisation of crop residues and the products of the daily household activities of the pre-Columbian population was incorporated into the soil by man and biological activity over hundreds and thousands of years (Lehmann et al., 2003). Figure 3 shows that, as a result of indigenous soil management, which has included the incorporation of charred debris and waste into the soil, the fertility of the indian dark earths is usually higher than the non-anthropogenic soils of the Amazon region.

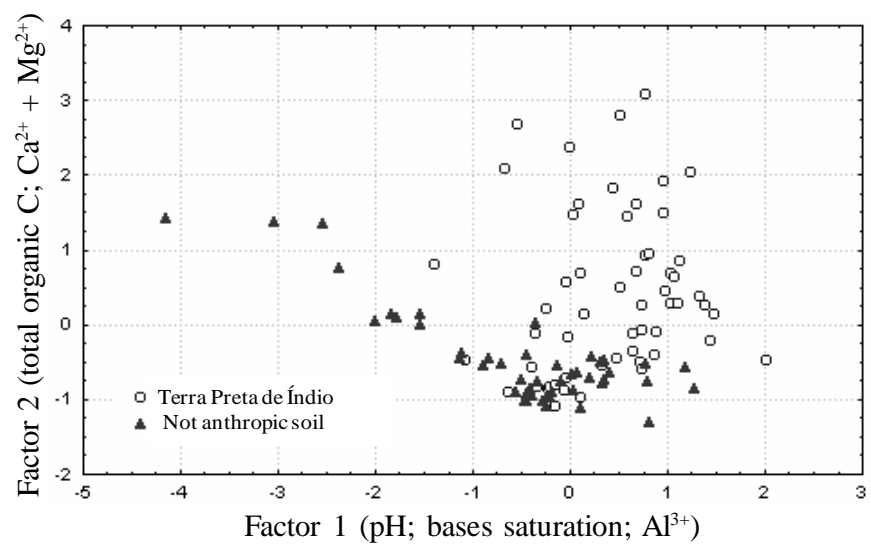

Figure 3. Diagram of the hierarchical analysis using fertility data of Terra Preta soils of the Amazon and nonanthropogenic soils (adapted from Madari et al., 2003)

This beneficial effect of charcoal probably required hundreds of years to be consolidated, mainly due to the size of the particles of carbon added to the soil and the time required for abiotic and biotic processes to oxidise the material, creating the desirable characteristics, which have since been attenuated (Kämpf \& Kern, 2005).

There is a trend of increasing microbial activity during the abiotic and biotic degradation of biochar in the soil (Kolb et al., 2009). Although abiotic degradation was primarily responsible initially, it can make an immediate contribution to increase microbial activity through the improvement of favourable and protected habitats (Hammes \& Schmidt, 2009).

The carbon in the anthropogenic dark earths is in relatively stable forms. The humic fractions of SOM, as it was observed by Cunha et al. (2007), feature different characteristics from those found in non-anthropogenic soils, and these differences are among the reasons for a higher fertility potential of these soils.

Using data obtained by ${ }^{13} \mathrm{C}$ VACP/MAS nuclear magnetic resonance (NMR) spectroscopy and multivariate analysis, 
Novotny et al. (2007) found that the humic acid fraction of SOM of anthropogenic dark earths contains carbon in structures that have the characteristics of pyrogenic source materials. This means that the humic acids of the anthropogenic dark earths inherited part of their structure from the pyrogenic material (i.e., charcoal), which has been built, accumulated and transformed in the soil for long periods of time. This situation contributed to improving the chemical and physical properties of the soil and, consequently, the formation of more fertile soils with a higher yield potential (Glaser et al., 2002).

Thus, although charcoal is a relatively inert material in the soil and has a high stability, depending on the conditions of its formation and the transformations that has undergone in the soil, it has the capacity to contribute to the improvement of the physical, chemical, and biological soil characteristics.

\section{ENVIRONMENTAL AND AGRONOMIC ASPECTS OF BIOCHAR} APPLICATION TO SOILS

The application of biochar to soil is also proposed as a mechanism for sequestering carbon $(\mathrm{C})$. Through this practice, the emission of $\mathrm{C}$ in the form of greenhouse gases would be prevented because the $\mathrm{C}$ is stored in the soil in a more stable form compared to the situation in which the residue was applied directly to the ground in more labile forms or even burned. In an attempt to calculate the effect of introducing a mechanism that adds stable $\mathrm{C}$ to the soil rather than simply burning biomass, Lehmann et al. (2006) estimated that up to $12 \%$ of the anthropogenic emissions of $\mathrm{C}$ caused by land-use change $(0.21$ $\mathrm{Pg} \mathrm{C}$ ) could be eliminated by applying $\mathrm{C}$ to the soil in the form of carbonised biomass.

The use of biochar in soil can lead to increased carbon sequestration because of its high structural stability due to its recalcitrant and refractory nature. However, the presence of pyrogenic $\mathrm{C}$ in the soil may also affect $\mathrm{C}$ accumulation through the $\mathrm{C}$ dynamics. Liang et al. (2010) measured that in an anthropogenic dark earth soil the incorporation of added organic matter in more stable fractions of SOM, like in aggregate and organo-mineral fractions, occurred in a larger extent than in a soil that did not have SOM of pyrogenic origin. However the exact mechanism behind the described phenomenon is still not known, it demonstrates the possible effect of charcoal addition on $\mathrm{C}$ sequestration in soil through SOM transformation.

The high specific surface area, large amount of chemically reactive sites and high porosity can reduce nitrous oxide $\left(\mathrm{N}_{2} \mathrm{O}\right)$ emissions from the soil, especially those due to nitrogen fertilisation, as observed by, for example, Yanai et al. (2007) and Zhang et al. (2011) in a calcareous loamy soil under a semihumid temperate monsoon climate. However, there are indications that the effect of biochar on GHG emission reductions is not straightforward and most probably depends on a variety of conditions such as the biochar source, application rate and soil characteristics. Karhu et al. (2011) observed reduction of $\mathrm{CH}_{4}$ emission by the application of biochar, but did not observe any effect on $\mathrm{CO}_{2}$ and $\mathrm{N}_{2} \mathrm{O}$ emissions in a well drained silt-loam soil in Southern Finland. According to the IPCC (2007), agriculture is considered one of the sectors of the economy that most contributes to the emissions of $\mathrm{N}_{2} \mathrm{O}$. Overall, it is estimated that agriculture accounts for $80 \%$ of $\mathrm{N}_{2} \mathrm{O}$ emissions (Cerri \& Cerri, 2007). In Brazil, this percentage is even higher due to the strong national vocation for agriculture: an estimated $87.2 \%$ of the $\mathrm{N}_{2} \mathrm{O}$ released annually into the atmosphere is from agricultural activity (grazing animals, use of synthetic fertilizers, residue decomposition and burning, cultivation of organic soils). In that context, and observing the importance of the savannah for grain production and the potential of Brazil for biochar production, the possible contribution of biochar application to the soil in the reduction of GHG emissions, especially $\mathrm{N}_{2} \mathrm{O}$, is a highly relevant issue to explore.

Another potential of biochar is its effect on the growth, development and productivity of agricultural crops and forestry, especially in tropical soils. According to Silva et al. (2008), organic matter is essential for the fertility of tropical soils due to the highly weathered state of the clay minerals in the soils that results in a low CEC. In tropical environments, the sustainable management of organic matter is of paramount importance; under sustainable management, it is possible to increase or maintain organic matter levels in the soil and thus maintain high CEC as well.

Several studies reported significant effects of stable carbon application on soil properties, crop physiology and yield. Among the earliest studies are those made by Tryon (1948), Iswaran et al. (1980) and Kishimoto \& Sugira (1985). In the last decade the number of studies regarding the evaluation of the benefits of charcoal application to the soil for soil quality, plant biomass production and crop yields multiplied (e.g., Lehmann et al., 2003; Oguntunde et al., 2004, Major et al., 2005; Madari et al., 2006; Steiner et al., 2007; Kimetu et al., 2008; Asai et al., 2009; Petter, 2010; Karhu et al., 2011; Laird et al., 2010; Zhang et al., 2011; Souchie et al., 2011). The beneficial physical and physical-chemical properties of biochar has been mentioned before. Due to these properties one of the most important effects of biochar is on the soil physical characteristics. Biochar reduces soil bulk density and, in general, increases soil water retention capacity (Laird et al., 2010; Karhu et al., 2011), however these effects are more pronounced in sandy textured soils (Madari et al., 2011).

The effect of biochar on plant available soil water is highly relevant as it is directly related to the milting point response of the plant which, in turn, directly relates to plant yields. Among the studies that bring results from field experiments Oguntunde et al. (2004) observed positive effect of charcoal on maize production and on the physical and chemical characteristics of the soil, highlighting increases in the grain yield and plant biomass of approximately 91 and 44\%, respectively. Major et al. (2005) found that the addition of carbon in the form of charcoal increased the biomass of rice plants by $53 \%$. Other positive effects of biochar application on yields were reported by Zhang et al. (2011) for maize and Steiner et al. (2007), Kimetu et al. (2008) and Asai et al. (2009) for upland rice, from different parts of the world. These results were achieved at generally relatively high application rates of over $8 \mathrm{Mg} \mathrm{ha}^{-1}$ (e.g., Karhu 
et al., 2011; Madari et al., 2011). Significant, and immediate, effects of biochar on increased nutrient availability and reduced soil acidity is also often observed in the literature. This is due to the high ash content of biochar, which is composed, mainly, of metals of basic reaction. A significant increase in the potassium availability, approximately $329 \%$, was reported by Oguntunde et al. (2004), on phosphorus (P), K, magnesium ( $\mathrm{Mg}$ ) and calcium (Ca) availability by Laird et al. (2010). More recently, Petter (2010) found significant effects of the application of biochar in the soil chemical properties and physiological response of soybean and rice in the Brazilian Savannah, observing increases in the levels of available P, K, $\mathrm{Ca}$ and $\mathrm{Mg}$ and reduction in the potential soil acidity, reducing the content of $\mathrm{Al}$, and an increase in the nutrient-use efficiency.

\section{ConClusion}

The technology of using biochar as soil conditioner in the Brazilian savannah is a promising future alternative to improve soil properties and the production of crops such as soybeans and aerobic rice in a sustainable manner.

\section{LITERATURE CITED}

Araújo Neto, S. E.; Azevedo, J. M. A.; Galvão, R. O.; Oliveira, E. B. L.; Ferreira, R. L. F. Produção de muda orgânica de pimentão com diferentes substratos. Ciência Rural, v.39, p.1408-1413, 2009.

Asai, H.; Samson, B. K.; Stephan, H. M.; Songyikhangsuthor, K.; Hommaa, K.; Kiyono, Y.; Inoue, Y.; Shiraiwa, T.; Horie, T. Biochar amendment techniques for upland rice production in Northern Laos. 1. Soil physical properties, leaf SPAD and grain yield. Field Crops Research, v.111, p.81-84, 2009.

Baldock, J. A.; Smernik, R. J. Chemical composition and bioavailability of thermally altered Pinus resinosa (Red pine) wood. Organic Geochemistry, v.33, p.1093-1109, 2002.

Bouwmann, A. F.; Germon, J. C. Introduction: Special issueSoils and climate change. Biology and Fertility Soils, v.27, p.219, 1998.

Brady, N. C.; Weil, R. R. The nature and properties of soils. 14.ed., Upper Saddle River: Prentice Hall, 2008. 965p.

Brennan, J. K.; Bandosz, T. J.; Thomson, K. T.; Gubbins, K. E. Water in porous carbons. Colloids and surfaces A: Physicochemical and engineering aspects, v.187-188, p.539-568, 2001.

Cerri, C.; Cerri, C. E. Agricultura e aquecimento global. Boletim Informativo da Sociedade Brasileira de Ciência do Solo, v.32, p.40-44, 2007.

Cohen-Ofri, I.; Weiner, L.; Boaretto, E.; Mintz, G; Weiner, S. Modern and fossil charcoal: aspects of structure and diagenesis. Journal of Archaeological Science, v.33, p.428-439, 2006.

Cunha, T. J. F.; Madari, B. E.; Benites, V. M.; Canellas, L. P.; Novotny, E. H.; Moutta, R. O.; Trompowsky, P. M.; Santos, G. A. Fracionamento químico da matéria orgânica e características de ácidos húmicos de solos com horizonte A antrópico da Amazônia (Terra Preta). Acta Amazonica, v.37, p.91-98, 2007.
Downie, A.; Crosky, A.; Munroe, P. Physical Properties of Biochar. In: Lehmann, J.; Joseph, S (ed.). Biochar for enviromental management: Science and Technology. 1. Londres: Earthscan, 2009. 416p.

Elizalde-Gonzales, M. P.; Mattusch, J.; Pelaez-Cid, A. A.; Wennrich, R. Characterization of adsorbent materials prepared from avocado kernel seeds: Natural, activated and carbonized forms. Journal of Analytical and Applied Pyrolysis, v.78, p.185-193, 2007.

Glaser, B.; Lehmann, J.; Zech, W. Ameliorating physical and chemical properties of highly weathered soil in the tropic with charcoal - A review. Biology and Fertility of Soils, v.35, p.219-230. 2002.

Hammes, K.; Schimidt, M. W. I. Changes of biochar in soil. In: Lehmann, J.; Joseph, S. (ed). Biochar for enviromental management: Science and technology. 1.ed., London: Earthscan, 2009. p.261-278.

Hammes, K.; Smernik, R. J.; Skjemstad, J. O.; Herzog, A.; Vogt, U. F.; Schmidt, M. W. I. Synthesis and characterisation of laboratory-charred grass straw (Oryza sativa) and chestnut wood (Castanea sativa) as reference materials for black carbon quantification. Organic Geochemistry, v.37, p.1629$1633,2006$.

IPCC - International Panel Climate Change. Climate change 2007: The Physical Science Bases. IPCC conference 2007. <http:/ /www.ipcc.ch. 5 Abr 2010

Iswaran, V.; Jauhri, K. S.; Sen, A. Effect of charcoal, coal and peat on the yield of moong, soybean and pea. Soil Biology Biochemestry, v.12, p.191-192, 1980.

Jantalia, C.P.; Resck, D.V.S.; Alves, B.J.R.; Zotarelli, L.; Urquiaga, S.; Boddey, R.M. Tillage effect on C stocks of a clayey Oxisol under a soybean-based crop rotation in the Brazilian Cerrado region. Soil \& Tillage Research, v.95, p.97-109, 2007.

Kämpf, N.; Kern, D. C. O solo como registro de ocupação humana pré-histórica na Amazônia. Tópicos em Ciência do Solo. Revista Brasileira de Ciência do Solo, v.4, p.277-320. 2005.

Karhu, K.; Mattila, T.; Bergström, I.; Regina, K. Biochar addition to agricultural soil increased $\mathrm{CH}_{4}$ uptake and water holding capacity - Results from a short-term pilot field study. Agriculture, Ecosystems and Environment, v.140, p.309-313, 2011.

Kimetu, J. M.; Lehmann, J.; Ngoze, S.; Mugendi, D. N.; Kinyangi, J.; Riha, S., Verchot, L.; Recha, J. W.; Pell, A. Reversibility of productivity decline with organic matter of differing quality along a degradation gradient. Ecosystems, v.11, p.726-739. 2008.

Kishimoto, S.; Sugira, G Charcoal as a soil condition. In: Symposium On Forest Product Research International: Achievements And The Future, 1985, Pretoria, Proceedings... Pretoria: National Timber Research Institute, 1985, v.5, p.22-26.

Kolb, S. E.; Fermanich, K. J.; Dornbush, M. E. Effect of charcoal quantity on microbial biomass and activity in temperate soils. Soil Biology \& Biochemistry, v.73, p.1173-1181, 2009.

Krull, E. S.; Skjemstad, J. O.; Graetz, D.; Grice, K.; Dunning, W.; Cook, G. D.; Parr, J. F. 13C-depleted charcoal from C3 and C4 grasses and the role of occluded carbon in phytoliths. Organic Geochemistry, v.34, p.1337-1352, 2003. 
Laird, D.A.; Fleming, P.; Davis, D. D.; Horton, R.; Wang, B.; Karlen, D. L. Impact of biochar amendments on the quality of a typical Midwestern agricultural soil. Geoderma, v.158, p.443-449, 2010.

Lehmann, J.; Gaunt, J.; Rondon, M. Bio-char sequestration in terrestrial ecosystems - A review. Mitigation and Adaptation Strategies for Global Change, v.11, p.403-427, 2006.

Lehmann, J.; Joseph, S. Biochar for enviromental management: An introduction. In: Lehmann, J.; Soseph, S. (ed). Biochar for enviromental management: Science and Technology. 1.ed. Londres: Earthscan, 2009. p.4-18.

Lehmann, J.; Silva, J. P. da; Steiner, C.; Nehls, T.; Zech, W.; Glaser, B. Nutrient availability and leaching in an archaeological Anthrosol and a Ferralsol of the Central Amazon basin: Fertilizer, manure and charcoal amendments. Plant and Soil, v.249, p.343-357, 2003.

Leij, F.; Wingate, J.; Hutchings, T. Charcoal as a potential tool for land and water remediation. In: $2^{\text {nd }}$ Conference Sustainable Urban Brownfield Regeneration: Integrated management, London, 2, 2006. Proceedings... Londres: Department of Mechanical Engineering at Imperial College, 2006. p.14-16.

Liang, B.; Lehmann, J.; Sohi, S.P.; Thies, J.E.; O’Neil, B.; Trujillo, L.; Gaunt, J.; Solomon, D.; Grossman, J.; Neves, E. G. Black carbon affects the cycling of non-black carbon in soil. Organic Geochemistry, v.41, p.206-213, 2010.

Lima, A. J. B.; Cardoso, M. G.; Guerreiro, M. C.; Pimentel, F. A. Emprego do carvão ativado para remoção do cobre em cachaça. Química Nova, v.29, p.247-250, 2006.

Machado, P. L. O. de A. Mecanismo de desenvolvimento limpo (MDL): funcionamento, pontos críticos e possibilidades para alguns sistemas agrícolas no Brasil. Rio de Janeiro: Embrapa Solos, 2003. 30p. Documentos, 41

Machado, P. L. O. de A. Carbono do solo e a mitigação da mudança climática global. Química Nova, v.28, p.329-334, 2005.

Madari, B. E.; Benites, V. M.; Cunha, T. J. F. The effect of management on the fertility of Amazonian dark earths. In Lehmann, J.; Kern, D. C.; Glaser, B.; Woods, W. I. (eds) Amazonian dark earths. Origin, properties, management. Kluwer: Dordrecht. 2003. p.407-432.

Madari, B. E.; Costa, A. R.; Castro, L. M.; Santos, J. L.; Benites, V. M.; Rocha, A. O.; Machado, P. L. O. A. Goiânia: EMBRAPA/Centro Nacional de Pesquisa de Arroz e Feijão. 2006. 4p. Comunicado Técnico 125.

Madari, B. E.; Petter, F. A.; Carvalho, M. T. M.; Silva, M. A. S. Efeito agronômico da aplicação de biomassa carbonizada em áreas agrícolas. In: Encontro Brasileiro de Substâncias Húmicas, 9, 2011. Aracaju. Anais... Aracaju: UFS. 2011. CD Rom

Major, J.; Steiner, C.; Ditommaso, A.; Falcão, N. P. S.; Lehmann, J. Weed composition and cover after three years of soil fertility management in the central Brazilian Amazon: Compost, fertilizer, manure and charcoal applications. Weed Biology Management, v.5, p.69-76, 2005.

Moura, A. P.; Campos, J. E.; Magalhães, S. R. Melhoria da qualidade de serviço na produção de carvão no setor de carbonização: um estudo de caso. Revista da Universidade Vale do Rio Verde, v.8, p.19-26, 2010.
Novotny, E. H.; Azevedo, E. R. de; Bonagamba, T. J.; Cunha, T. J. F.; Madari, B. E.; Benites, V. M.; Hayes, M. H. B. Studies of the compositions of humic acids from Amazonian Dark Earth soils. Environmental Science \& Technology, v.41, p.400-405, 2007.

Novotny, E. H.; Hayes, M. H. B.; Madari, B. E.; Bonagamba, T. J.; de Azevedo, E. R.; de Souza, A. A.; Song, G.; Nogueira, C. M.; Mangrich, A. S. Lessons from the Terra Preta de Índios of the Amazon Region for the utilization of charcoal for soil amendment. Journal of Brazilian Chemical Society, v.20, p.1003-1010, 2009.

Oguntunde, P. G.; Fosu, M.; Ajayi, A. E.; Giesen, N. V. Effects of charcoal production on maize yeld, chemical properties and texture of soil. Biology and Fertility of Soils, v.39, p.296-299. 2004.

Pacheco, L. P.; Petter, F. A. Benefits of cover crops in soybean plantation. In: Brazilian Cerrados. In: Tzi Bun Ng (ed). Soybean - Applications and Technology, 2011. p.67-94.

Pereira, E.; Oliveira, L. C. A.; Vallone, A.; Sapag, K.; Pereira, M. Preparação de carvão ativado em baixas temperaturas de carbonização a partir de rejeitos de café: Utilização de $\mathrm{FeCl}_{3}$ como agente ativante. Química Nova, v.31, p.12961300, 2008.

Pessenda, L. C. R.; Gouveia, S. E. M.; Aravena, R.; Boulet, R.; Valencia, E. P. E. Holocene fire and vegetation changes in southeasterm Brazil as deduced from fóssil charcoal and soil carbon isotopes. Quaternary International, v.114, p.3543. 2004.

Petter, F. A. Biomassa carbonizada como condicionador de solo: aspectos agronômicos e ambientais do seu uso em solos de cerrado. Goiânia: UFG, 2010. 130p. Tese Doutorado

Rouquerol, F.; Rouquerol, I.; Sing, K. Adsorption by powders and porous solids, London: Academic Press, 1999. 125p.

Santiago, A. R.; Andrade, A. M. Carbonização de resíduos do processamento mecânico da madeira de eucalipto. Ciência Florestal, v.15, p.1-7, 2005.

Sato, C. E.; Azevedo, E. M. Créditos de carbono no contexto da comercialização de energia elétrica. Revista Brasileira de Energia, v.14, p.9-25, 2008.

Silva, V.A.; Marchi, G; Guilherme, L. R. G; Lima, J. M.; Nogueira, F. Guimarães, P. T. G. Kinetics of K release from soils of Brazilian coffee regions: effect of organic acids. Revista Brasileira de Ciência do Solo, v.32, p.533-540, 2008.

Souchie, F. F.; Marimon Junior, B. H.; Petter, F. A.; Madari, B. E.; Marimon, B. S.; Lenza, E. Carvão pirogênico como condicionante para substrato de mudas de Tachigali vulgaris L.G. Silva \& H.C. Lima. Ciência Florestal, v.21, n.4, p.811-821, 2011.

Souza, F. J de.; Azevedo, P. F. de. Geração de energia elétrica excedente no setor sucroalcooleiro: um estudo a partir das usinas paulistas. Revista de Economia e Sociologia Rural, v.44, p.179-199, 2006.

Steiner, C.; Teixeira, W. G.; Lehmann, J.; Nehls, T.; Macêdo, J. J. V.de; Blum, W. E. H.; Zech, W. Long term effects of manure, charcoal and mineral fertilization on crop production and fertility on a highly weathered Central Amazonian upland soil. Plant and Soil, v.291, p.275-290, 2007. 
Torres, J. L. R.; Pereira, M. G.; Andrioli, I.; Polidoro, J. C.; Fabian, A. J. Decomposição e liberação de nitrogênio de resíduos culturais de plantas de cobertura em um solo de cerrado. Revista Brasileira de Ciência do Solo, v.29, p.609-618, 2005. Trompowsky, P. M.; Benites, V. M.; Madari, B. E.; Pimenta, A. S.; Hockaday, W. C.; Hatcher, P. G. Characterization of humic like substances obtained by chemical oxidation of eucalyptus charcoal. Organic Geochemistry, v.36, p.14801489, 2005.

Tryon, E. H. Effect of charcoal on certain physical, chemical, and biological properties of forest soils. Ecology Monography, v.18, p.81-115, 1948.

Tsai, W. T.; Lee, M. K.; Chang, Y. M. Fast pyrolyses of rice rusk: Product yields and composition. Bioresource Techology, v.98, p.22-28, 2007.
Wildman, J.; Derbyshire, F. Origins and functions of macroporosity in activated carbons from coal and wood precursors. Fuel, v.70, p.655-661, 1991.

Yanai, Y.; Toyota, K.; Okazaki, M. Effects of charcoal addition on $\mathrm{N}_{2} \mathrm{O}$ emissions from soil resulting from rewetting airdried soil in short-term laboratory experiments. Soil Science and Plant Nutrition, v.53, p.181-188, 2007.

Yang, H.; Yan, R.; Chen, H.; Lee, D. H.; Zheng, C. Characteristics of hemicelulose, cellulose and lignin pyrolysis. Fuel, v.86, p.1781-1788, 2007.

Zhang, A.; Liu, Y.; Pan, G.; Hussain, Q.; Li, L.; Zheng, J.; Zhang, $X$. Effect of biochar amendment on maize yield and greenhouse gas emissions from a soil organic carbon poor calcareous loamy soil from Central China Plain. Plant and Soil, v.351, p.263-275, 2011. 